\title{
SUCESSÃO E CONFLITOS EM EMPRESAS FAMILIARES: ESTUDO DE CASOS MÚLTIPLOS EM EMPRESAS NA CIDADE DE ARACAJU
}

SUCESSION AND CONFLICTS IN FAMILY BUSINESSES: A MULTIPLE CASE STUDY OF BUSINESSES IN THE CITY OF ARACAJU

\section{SUCESIÓN Y CONFLICTOS EN EMPRESAS FAMILIARES: ESTUDIO DE CASOS MÚLTIPLES EN EMPRESAS EN LA CIUDAD DE ARACAJU}

Rivanda Meira Teixeira

$\mathrm{PhD}$.

Universidade Federal de Sergipe

rivandateixeira@terra.com.br

Felipe Carvalhal

Graduado

Universidade Federal de Sergipe

felipe-c-b@hotmail.com

Submetido em: 02/12/2012

Aprovado em: 01/07/2013

\section{RESUMO}

Apesar de inúmeros estudos realizados sobre a sucessão na empresa familiar tanto no Brasil quanto no exterior, essa questão continua sendo uma das mais críticas enfrentadas pelas empresas familiares. Esse estudo analisa como ocorre o processo de sucessão nas empresas familiares e identifica os conflitos existentes entre fundadores e herdeiros na percepção do herdeiro. O estudo de casos múltiplos foi realizado com quatro empresas familiares, cujos fundadores e herdeiros estivessem na direção do negócio. Evidências foram coletadas por meio de entrevistas pessoais semiestruturadas com pelo menos um herdeiro, e depois foram analisadas com a adoção da técnica de análise de conteúdo. Ao se comparar o processo de sucessão e os seus conflitos nos casos analisados, observou-se que não ocorreram conflitos na escolha dos sucessores e que é percebida também a intenção do herdeiro para assumir a empresa no futuro. Quanto aos conflitos, verificou-se que eles aparecem principalmente relacionados às questões financeiras, embora de maneira geral eles não fossem muito relevantes.

PALAVRAS-CHAVES: Empresas familiares. Sucessão. Conflitos.

ABSTRACT

Despite numerous studies on succession in family businesses, both in Brazil and abroad, this still remains one of the most critical issues faced by this type of business. This study analyses the process of succession in family businesses, and identifies the conflicts that exist between the founders and their heirs, from the perspective of the heirs. This multiple case study was conducted with four family-owned companies, whose founder and heirs were managing the business. Evidence was collected through semi-structured interviews with at least one heir, and was later analyzed using the technique of content analysis. Comparing the processes of succession and its conflicts in the cases analyzed, it was observed that there were no conflicts in the choice of successors and that there was an intention, on the part of the heir, to take over 
the company in the future. As for the conflicts that did exist, it was found that these were mainly related to financial issues, but that in general, these were not significant.

KEY WORDS: Family Business. Succession. Conflicts.

\section{RESUMEN}

A pesar de los innumerables estudios realizados sobre la sucesión en la empresa familiar, tanto en Brasil como en el exterior, esa cuestión continúa siendo una de las más críticas enfrentadas por las empresas familiares. Este estudio analiza cómo ocurre el proceso de sucesión en las empresas familiares e identifica Ios conflictos existentes entre fundadores y herederos desde el punto de vista del heredero. El estudio de casos múltiples fue realizado con cuatro empresas familiares cuyos fundadores y herederos estaban en la dirección del negocio. Se recolectaron evidencias por medio de entrevistas personales semiestructuradas con al menos un heredero, y después se analizaron con la adopción de la técnica de análisis de contenido. Al comparar el proceso de sucesión y sus conflictos en los casos analizados, se observó que no ocurrieron conflictos en la elección de los sucesores y se percibe también la intención del heredero de asumir la empresa en el futuro. En cuanto a los conflictos, se verificó que aparecen principalmente relacionados a las cuestiones financieras, aunque de manera general no son muy relevantes.

PALABRAS CLAVE: Empresas familiares. Sucesión. Conflictos.

\section{INTRODUÇÃO}

Tendo em vista sua expressividade em termos de quantidade, capacidade de geração de empregos e contribuição para a riqueza de um país, autores como Mussi, Teixeira e Massukado (2008) destacam a necessidade de aprimorar o entendimento a respeito desse tipo de organização particular e dos elementos que a constituem, assim como das contingências inerentes que emergem de sua dinâmica interna. Para Bernhoeft (1989), a importância das empresas familiares está no fato de representar uma das maiores geradoras de emprego e de provocar a descentralização dos polos regionais de desenvolvimento, gerando aumento do mercado consumidor e melhorando a distribuição de renda. Puga (2006) afirma que as empresas familiares são responsáveis diretas pelo desenvolvimento social, gerando oportunidades de inclusão em nossa sociedade por meio da criação de aproximadamente $75 \%$ dos novos empregos e pela manutenção de $85 \%$ dos empregos existentes.

Nos Estados Unidos, estima-se que aproximadamente $60 \%$ das empresas sejam desta natureza (ALLIO, 2004). Ricca (2005) destaca que, das oito milhões de empresas existentes no Brasil, 90\% são familiares, responsáveis pela geração de dois milhões de empregos diretos no país, participando com $12 \%$ no Produto Interno Bruto nos agronegócios, 34\% na indústria e 54\% na área de serviços.

Entre as principais vantagens das empresas familiares, pode-se destacar lealdade entre os membros da família e a disposição dos consanguíneos para se sacrificarem em tempos de crise (DAVIS, 1983; KETS DE VRIES, 1993); o compartilhamento de objetivos comuns, de valores e significados (LONGENECKER; MOORE; PETTY, 1997); a perspectiva de longo prazo; zelo pela reputação da empresa que, em certas situações, se confunde e se sobrepõe à reputação do seu fundador; facilidade em manter o foco no seu core business (KETS DE VRIES, 1993; ALLIO, 2004). Entre as suas principais desvantagens, cabe destacar os efeitos negativos da sobreposição das entidades família e empresa, a dificuldade de separar as ações familiares das decisões profissionais, a supervalorização das relações afetivas, as relações autoritárias e paternalistas e o nepotismo (PEISER; WOOTEN, 1983).

Estudos apontam que as chances de sobrevivência para empresas familiares diminuem a cada nova geração presente no negócio (DUARTE, 2006, p. 12). Para Oliveira (1999), a expectativa média de vida para as empresas não familiares no Brasil é de doze anos, para as de controle familiar é de apenas nove, apenas 30\% delas chegam à segunda geração e $9 \%$ à terceira geração. 
Macedo (2008) argumenta que uma das prováveis explicações para esses problemas é a transição de liderança, pois se sabe que nem sempre ocorre a partir de um planejamento, mas pela impossibilidade do empresário de continuar à frente do negócio. O mesmo autor cita ainda que transição de liderança nas empresas familiares envolve aspectos profissionais e emocionais, pois a tendência é que a transição aconteça para um membro da família. Outra explicação para justificar a mortalidade de tais empresas é a questão relacionada aos conflitos dentro da empresa familiar.

Esta pesquisa está focada em dois aspectos centrais que são abordados nos estudos sobre empresas familiares: a sucessão e os conflitos entre os fundadores e os herdeiros. A sucessão, segundo Leone (2002), é o rito de transferência de poder e capital entre a geração que atualmente dirige e a que virá a dirigir, podendo acontecer de forma gradativa e planejada, ou quando por ocasião de morte, acidente ou doença do dirigente, de forma repentina. A despeito dos inúmeros estudos já realizados, Campbell, Heriot e Welsh $(2007$, p.9) consideram que este processo de sucessão "continua sendo uma caixa preta e encontra-se entre as questões mais críticas de investigação enfrentadas pelos estudiosos da empresa familiar".

Porém, apesar do reconhecimento da importância de tal processo, ainda é grande o número de fundadores que não planejam a entrega da condução dos negócios nas mãos dos herdeiros. Essa falta de planejamento se dá pelas dificuldades que envolvem o processo sucessório. Bernhoeft (1989) cita algumas dessas complexidades: divergência entre sócios; número excessivo de sucessores; desinteresse dos sucessores pelo negócio; diferenças muito marcantes na participação acionária; divergências entre familiares; e insegurança dos funcionários quanto ao futuro da empresa.

Além dos problemas citados anteriormente, existe um fator relevante que leva o fundador a relutar em transferir a gestão para o sucessor. Leone (2002) cita que existe um verdadeiro apego sentimental do criador da empresa ao seu negócio, porque ele não considera a empresa como um simples bem que pode deixar para seus filhos após anos de muito sacrifício.

Segundo Bertucci et al. (2008), outro ponto relevante na análise do processo sucessório é o fato de os membros da família apresentarem diferentes interesses em relação à empresa. Contudo, torna-se necessário a criação de elementos de coesão capazes de unir os interesses dos membros da família. Essa coesão é um dos elementos fundamentais para possibilitar uma transição negociada de uma geração para outra e para a perpetuação dos negócios da família. As transições constituem geralmente os momentos mais difíceis por que passa a empresa familiar.

Bornholdt (2005, p. 83) cita que governar uma empresa familiar é saber lidar com toda a complexidade das relações afetivas e financeiras existentes na organização, com as inúmeras diferenças de interesse entre familiares e demais pessoas envolvidas no processo de gestão empresarial e, principalmente, com os inevitáveis conflitos que, não sendo bem administrados, podem levar à destruição de uma instituição. Como respeito aos conflitos nessas empresas, Bornholdt (2005) destaca ainda os originados da relação entre pais e filhos; brigas entre irmãos; entre cônjuges; e entre tio e primos.

Em função do contexto apresentado, é colocado o seguinte problema de pesquisa: Como ocorre a sucessão e quais são os principais conflitos existentes, na percepção do herdeiro, entre fundadores e herdeiros em pequenas empresas familiares de Sergipe?

Após ser delineado o problema de pesquisa, foram traçados os objetivos do estudo. O objetivo geral é analisar a sucessão e os conflitos existentes em empresas familiares na cidade de Aracaju, Sergipe, e especificamente pretende verificar as principais características dessas empresas familiares; descrever o perfil dos fundadores e dos herdeiros; analisar como ocorre o processo de sucessão e identificar os conflitos existentes entre fundadores e herdeiros nessas empresas.

Este estudo pretende contribuir na medida em que vai estudar dois aspectos centrais abordados nos estudos sobre empresas familiares: a sucessão e os conflitos entre os fundadores e os membros da família. Segundo Vidigal (1996), a divergência de ideias entre fundador e herdeiro, muitas vezes, impede a empresa de crescer, porque em geral a resistência às mudanças, principalmente por parte do fundador, faz com que a empresa não se adapte às inovações exigidas pelo mercado. Constanzi e Lanzana (1999) caracterizam as empresas familiares pela centralização das decisões e dos conflitos que, por vezes, dificultam a sobrevivência dessas no mercado competitivo e concorrencial. A análise e a compreensão dos conflitos existentes nas empresas familiares por meio do entendimento das 
relações entre fundador e herdeiro podem ajudar a entender melhor a dinâmica nessas empresas e podem fornecer contribuições teóricas e práticas.

\section{EMPRESAS FAMILIARES}

Apesar da relevância e de muitos estudos sobre empresas familiares, a definição de empresa familiar é bem delicada e ainda gera algumas discussões (GRZESZCZESZYN; MACHADO, 2009; LESCURA et al., 2009; SOUSA, AMARAL, 2008). Uma das dificuldades em definir o que é uma empresa familiar está alicerçada na complexidade da sobreposição dos fatores empresarial e familiar na organização.

Diante da dificuldade de conceituação do que venha a ser empresa familiar, três vertentes conceituais se destacam. A primeira é o fato de a propriedade da empresa ser de uma família; a segunda é que a gestão da empresa esteja nas mãos de familiares; e a terceira vertente é baseada na questão da sucessão familiar (LEONE, 2005). A primeira no nível da propriedade, em que o controle da empresa encontra-se nas mãos de uma família, que detém ou controla a maioria do capital; a segunda está no nível da gestão, em que os lugares de topo da empresa são ocupados pelos membros da família; e a terceira vertente encontra-se no nível da sucessão, sendo que a segunda geração familiar assume os lugares deixados vagos pelos parentes e, assim, sucessivamente (GRZESZCZESZYN; MACHADO, 2009).

Para Donneley (1964), pioneiro nesse campo de estudo, as empresas familiares seriam aquelas perfeitamente identificadas com uma família há pelo menos duas gerações, sendo caracterizada quando esta ligação implica uma influência recíproca na política geral da organização, e nos interesses e nos objetivos da família; para ele, se não houver sucessão, não há empresa familiar.

Bernhoeft (1989) buscou adequar conceitos de estudos americanos, apresentados por Donnelley, à realidade brasileira. Ele aponta algumas características que tornam uma organização familiar nos moldes brasileiros, que são: confiança mútua, estreitos laços afetivos influenciando os comportamentos e as decisões empresariais, valorização da antiguidade nos critérios de promoção dos funcionários, exigência de dedicação com expectativa de fidelidade e postura severa do gestor. Essas características demonstram dificuldades gerenciais em separar o emocional do racional, em que jogos de poder entre membros da família são aceitos em função da boa administração da empresa.

Lodi (1993) complementa as colocações de Bernhoeft (1989) e de Donnelley (1964). Segundo o autor, a empresa familiar é aquela em que a sucessão da diretoria está ligada ao fator hereditário, e os valores institucionais da firma se identificam com o sobrenome da família empresária ou com a figura do fundador. $\mathrm{O}$ autor argumenta que o empreendimento com um fundador sem herdeiros não é uma empresa familiar, assim como aquela em que a família apenas investe o dinheiro sem exercer cargos de administração ou influência na gestão.

Para Cattani (1992), a empresa familiar assenta-se sobre os subsistemas família e negócio, em que, embora cada um tenha suas próprias normas, regras e estruturas, qualquer mudança introduzida num dos subsistemas, fatalmente, irá provocar mudanças nos demais. Para o autor, encontrar estratégias que os satisfaçam mutuamente é o ponto-chave da empresa familiar.

Com visão contrária a Donneley (1964), Litz (2008) compreende que uma empresa se torna familiar quando busca apoio em recursos familiares específicos, e para isso se vincula ou passa a depender de uma família. Verifica-se aqui que o fator sucessório já não se apresenta como determinante na classificação desses empreendimentos.

Em uma perspectiva mais atual e com enfoque mais econômico, Kelm e Schorr (2011) explicitam que empresa familiar nada mais é que uma organização que visa ao lucro por meio do capital empregado pela família proprietária, portanto, as empresas familiares reúnem relações familiares e laborais, tornando-se universos complexos, os quais devem ser entendidos sempre com olhares que se alternam entre a focagem no todo e a percepção sobre o funcionamento das partes.

Para este estudo, será adotada a definição de Donneley (1964) de empresa familiar, em que é preciso existir duas gerações da família no controle da empresa, caso contrário, não será caracterizada como empresa familiar. 
Como características destas empresas estão a sensibilidade social e política do grupo familiar, em nível regional e nacional; a reputação que o nome da família pode ter no espaço geográfico onde atua, funcionando como uma espécie de segurança econômica e política; além dos valores familiares, dentre os quais, austeridade, comprometimento, dedicação e a liderança, constituem elementos importantes para o desenvolvimento em que estão inseridas as organizações familiares (GRZESZCZESZYN; MACHADO, 2009). Logo, de acordo com a intensidade e a regularidade de tais características, as empresas familiares podem influenciar beneficamente, de formas distintas, as pessoas e a sociedade na qual se encontram, percebendo assim sua importância de atuação e permanência no mercado (BEUREN; MÜLER, 2010; GRZESZCZESZYN; MACHADO, 2009). Segundo Kets de Vries (1993), as empresas familiares tendem a ter uma visão de longo prazo na condução de seus negócios e pouco se arriscam em troca de ganhos de curto prazo quando percebem que isso pode manchar sua reputação.

\section{Sucessão nas Empresas Familiares}

Biehl e Silveira (2003) apresentam que, após a transformação do empreendimento individual em familiar, a perpetuação torna-se uma preocupação essencial do ciclo de vida da organização. Essa perpetuação acontece com o processo sucessório, considerado o ápice da empresa familiar, interferindo nos negócios empresariais de forma decisiva, podendo determinar estabilidade, expansão ou declínio da organização, ele envolve, além da transmissão gerencial e patrimonial, a transferência ideológica do sucedido para o sucessor (BIEHL; SILVEIRA, 2003; LESCURA et al., 2010b).

Ibrahim e Ellis (2004) apresentam que, enquanto o fundador da empresa se estabelece como principal gestor por aproximadamente 32,4 anos, um chief executive officer (CEO) permanece nessa mesma posição por cerca de 7 anos em média em empresas não familiares. É possível perceber, então, que a retirada do fundador representa uma enorme ruptura nas empresas familiares, devido à sua influência na gestão, nos interesses da empresa e da sua família, e por conta do tempo de permanência no cargo (LONGNECKER; MOORE; PETTY, 1997). Já as empresas não familiares preocupam-se mais em adaptar-se às mudanças do mercado rapidamente, para isso buscam mudar seus principais gestores para acompanhar tais mudanças, trazendo maior dinamismo e uma nova visão ao negócio.

Uma preocupação relatada por Allio (2004) refere-se à passagem da empresa para as gerações seguintes, de acordo com ele somente $30 \%$ das empresas familiares chegam à segunda geração; $12 \%$, à terceira geração e 3\%, à quarta geração. Complementando, Gersick et al. (2006) afirmam que $40 \%$ das empresas familiares fracassam no primeiro ano de vida, $60 \%$, em menos de dois anos e $90 \%$, até o final do décimo ano.

Miller, Streier e Le Breton Miller (2003) em seu estudo com dezesseis casos de fracasso no processo sucessório, concluíram que a razão principal para tais falhas residia na ausência de alinhamento entre o passado e o futuro da empresa, responsabilidade principal dos fundadores e dos herdeiros do negócio.

Para Cançado et al. (2010), boa parte do fracasso deve-se ao entendimento errôneo de que sucessão é um evento isolado, cuja finalidade restringe-se a simples transferência de poder. De acordo com Mussi, Teixeira e Mussukado (2008), o processo sucessório constitui uma alteração organizacional que impacta, de forma significativa, em todo o sistema, uma vez que tal processo interfere: a) na família: no tocante ao tempo que o fundador passa com ela, dos impactos psicológicos causados pela sua retirada da empresa que, em muitas situações, constitui sua história de vida e, também, em maior ou menor grau, as alterações provocadas na sua renda; b) na gestão: não necessariamente o sucessor adotará as mesmas práticas e modo de administrar a empresa que seu antecessor, visto que suas capacidades técnicas e gerenciais, assim como seus objetivos e experiências anteriores, podem diferir significativamente daquelas presentes no sucedido; c) na empresa: alterações, em maior ou menor grau, podem ocorrer antes, durante e, especialmente, após o processo de sucessão, tanto no tocante aos métodos e às relações de trabalho, às práticas, aos valores e aos rituais institucionalizados e legitimados pelos empregados, quanto aos resultados financeiros.

Oliveira (1999) identifica dois tipos de processo sucessório nas empresas familiares, a sucessão familiar e a sucessão profissional. No primeiro caso, exige-se uma análise real do processo sucessório para não se avaliar equivocadamente, afirmando que os herdeiros naturais são os melhores dirigentes 
para a empresa, passando, assim, a gestão da empresa para um membro da família mais capacitado de acordo com os critérios tomados por seu fundador. No segundo caso, a empresa familiar passa a ser administrada por profissionais contratados, os executivos passam a ocupar cargos diretivos da empresa familiar e os representantes da família ficam em um conselho, que pode ou não atuar como um conselho de administração. Biehl e Silveira (2003) ressaltam que, em ambos os casos, o planejamento é fundamental, tendo como ponto central a escolha do sucessor e orientado por critérios claros que defendam os interesses da empresa.

Os fundadores de empresas familiares são pessoas que constroem suas vidas a partir de sacrifícios e sucessos. De acordo Biehl e Silveira (2003), estas personagens têm seu valor reconhecido por meio dos sentimentos que despertam, sejam de admiração ou de inveja, ou no exemplo daquilo que fazem por meio da contribuição que dão à sociedade. Os herdeiros e as herdeiras de empresas familiares têm seu comportamento muito visado pelos próprios pais, pela família e pela sociedade. No contexto destas expectativas, diversas vezes os pais constroem a empresa, mas equivocadamente, se esquecem de analisar um dos fatores determinantes da continuidade do negócio familiar; a preparação dos herdeiros para serem as novas lideranças.

Brockhaus (2004) afirma que os critérios para a seleção de sucessores estariam relacionados com sua formação profissional, suas habilidades técnicas e gerenciais, bem como a intenção dos sucessores em participar da empresa familiar. Ainda no tocante ao processo sucessório, é importante enfocar um recorte quanto à presença e à incidência de possíveis conflitos que permeiam as relações vivenciadas nas empresas familiares, que podem interferir positiva ou negativamente nesta etapa. Dentre elas, destacam-se as relações familiares, em especial a de pais e filhos, por considerá-las relevantes na definição da carreira e, consequente, no processo sucessório em uma empresa familiar (MERHI et al., 2010).

Rossato Neto (2008, p.12) destaca que "o pai prepara o filho não para ser seu sucessor, mas para ser sua sombra". Caso os filhos assumam no futuro a empresa, o fazem depois da morte do pai, ou no período em que ele não tem mais condições de fazê-lo. Muitas vezes os filhos se veem no dilema entre assumir a empresa do pai e seguir a sua própria carreira em outra empresa, que não seja da família. Ele reforça ainda mais: "Para assumir a organização familiar, é necessário que esse filho 'mate' simbolicamente esse pai, e reconheça suas virtudes e fraquezas, assim como as suas próprias" (p.12).

A escolha do primogênito dá-se em grande parte das famílias empresárias. Segundo Gersick et al. (2006), as famílias sentem-se incomodadas com a competição explícita e a avaliação entre irmãos e acabam optando por regras como a primogenitura, que poupa os pais de se expor ao favoritismo, ou a sensação de recriminação de algum filho. Merhi et al. (20010) ressaltam que esta opção acaba sendo a mais comum e automática aplicada para a escolha do sucessor. "A primogenitura é uma regra arbitrária, baseada em valores familiares a respeito de idade e sexo, o que pode deixar os irmãos com ressentimentos capazes de influenciar seus relacionamentos pelo resto das suas vidas" (GERSICK et al., 2006).

Kets de Vries (1993) relata que o sucessor, especialmente no caso do primogênito, é uma situação ainda mais difícil, isto porque este pode viver sob a sombra do fundador que, muitas vezes, possui personalidade dominante, pois o fundador pode, inconscientemente, sentir-se ameaçado e menosprezar o filho, agredindo-o e tentando desacreditá-lo. Nesse caso, as altas expectativas podem tornar o sucessor inseguro quanto à sua capacidade de continuar o legado familiar, vendo o pai como um gigante inalcançável.

Tondo (2008) aconselha que haja uma construção conjunta entre gerações, cujos espaços sejam disponibilizados tanto para os mais velhos quanto para os mais novos, visando ao respeito mútuo, observando-se individualidades e características pessoais, não deixando de ter como objetivo a continuidade dos negócios com a gestão da família, reforçando a que, como defende Oliveira (2006, p. 22), "as pessoas não são eternas, mas as empresas podem ser".

A questão do gênero começa a ser sinalizada e pode ter ainda outra implicação nos processos de sucessão de empresas, que é a ligada ao estilo gerencial do sucedido. Neste sentido, o preparo de sucessores, que em geral era centrado na relação de pais e filhos, hoje tem como possibilidades múltiplas relações, envolvendo: mãe e filha (s); mãe e filho (s); pai e filho (s); pai e filha (s), e tornando-se a melhor opção (MACHADO, 2003). 
De qualquer forma, a sucessão é um processo complexo, cuja representação é um somatório de obstáculos (DUARTE, 2006). Os proprietários e os familiares devem se comprometer a construírem uma visão de uma futura estrutura de controle e decidir como dividir as ações em concordância com a mesma. Da mesma forma, precisam planejar a sucessão, desenvolvendo e treinando os sucessores em potencial para a gestão e montar um processo para a seleção dos líderes mais bem preparados e qualificados A estratégia para o processo sucessório não pode ser uma preocupação exclusiva do âmbito familiar: ela deve envolver outros colaboradores e conselheiros profissionais. Pode ocorrer que o fundador não deseje passar o negócio a seus filhos. Dessa forma, a estratégia pode se resumir à procura de um novo líder sem vínculo familiar (TUCKER, 2006).

A sucessão pode propiciar resultados distintos à dinâmica das empresas familiares. Esse processo pode impulsionar o crescimento da organização a partir da inserção de novas práticas de gestão e direcionamentos estratégicos (TILLMANN; GRZYBOVSKI, 2005); contudo, também pode determinar a falência da empresa familiar, a partir do surgimento de conflitos familiares inerentes à dinâmica entre família e empresa (HAVEMAN; KHAIRE, 2004). Desse modo, dentro de uma perspectiva estratégica, é a forma como o processo de sucessão ocorre que influencia a possibilidade de continuidade dos negócios sob o controle da família empresária (BORGES; LIMA, 2009).

A falta de planejamento para o processo sucessório é tido por Garcia (2001), assim como para outros autores, como o mais relevante entre os pontos negativos de uma empresa familiar. Para Cançado et al. (2010), boa parte do fracasso deve-se ao entendimento errôneo de que sucessão é um evento isolado, cuja finalidade restringe-se a simples transferência de poder. Segundo Biehl e Silveira (2003), este é um processo que precisa ser tratado com atenção, pois ele visa à coordenação futura da empresa. Bernhoeft (1989) segue na linha de dos autores citados anteriormente, na visão dele, a sucessão deve ser encarada como um processo que pressupõe a definição de atividades programadas e temporais, bem como a delimitação clara de papéis para as diferentes partes envolvidas.

Scheffer (1995), em um estudo realizado com empresas familiares, elenca uma diversidade de dificuldades relacionadas ao processo sucessório: 1) quando o sucessor não está suficientemente capacitado; 2) quando as interações familiares se interpõem nos negócios; 3) quando o fundador ou o principal gestor se recusa a sair do cargo; 4) quando os funcionários mais antigos rejeitam a sucessão e; 5) quando o potencial sucessor não se interessa pelos negócios da família. Lescura et al. (2010a) destacam que essa diversidade de dificuldades encontradas no processo sucessório faz emergir conflitos de toda ordem nessas organizações. Segundo os autores, podem ocorrer disputas entre os sucessores, desentendimentos entre o progenitor e o herdeiro, bem como o desinteresse por parte dos descendentes em dar continuidade ao empreendimento. Estes conflitos ocorrem, na visão de Grzybovski e Tedesco (1998), porque a sucessão é um processo delicado e, segundo Bernhoeft (1989), questões emocionais não resolvidas no âmbito familiar podem surgir no processo sucessório sob forma de vaidades, chantagens e disputas.

\section{Conflito em Empresas Familiares}

De acordo com Rondeau (1996), o conflito pode ocorrer no nível individual ou em grupo; ele surge quando uma parte, o indivíduo ou o grupo, percebe a outra como obstáculo à satisfação de suas preocupações, o que provoca sentimento de frustração que levará a reagir em face da outra parte. Já Follet (1997) associa o conflito às diferenças e não é possível evitá-lo, mas utilizá-lo. Em vez de condená-lo, deve-se fazer do mesmo uma busca para os benefícios. Enquanto Robbins (2002) adota definição semelhante à de Rondeau, e o vê "um processo que tem início quando uma das partes percebe que a outra parte afeta, ou pode afetar, negativamente, alguma coisa que a primeira considera importante".

Beutell e Greenhaus (1985), assim como Carlson, Kacmar e Stepina (1995), sugerem que podem existir conflitos familiares ou no trabalho quando a atuação do indivíduo em um dos papéis dificulta o cumprimento das exigências do outro em função do tempo dedicado nas atribuições, da tensão provocada pela participação e dos comportamentos específicos exigidos por estes. Para Brito, Silva e Muniz (2010), a proximidade entre as esferas família e empresa pode dificultar o processo de gestão à medida que os interesses diferentes podem gerar tensões e levar, em alguns casos, a conflitos de difícil resolução que precisam ser administrados corretamente. Segundo os autores, isto 
acontece porque os relacionamentos entre membros da família numa empresa são mais delicados do que entre empregados sem vínculos familiares entre si.

Segundo Brito, Silva e Muniz (2010), esta visão é baseada na teoria dos papéis, que fornece uma compreensão para o estudo dos conflitos entre trabalho e família, porque ela assume a existência de uma pressão mútua e incompatível entre papéis. De acordo a com essa teoria, o conflito pode ser baseado em três fatores: (1) tempo - quando um dos domínios exige uma maior participação em detrimento da presença no outro domínio, por exemplo, excessiva dedicação ao trabalho, impedindo que o homem, ou a mulher, cumpra seu papel na família; (2) tensão - quando as tensões existentes devido a um dos domínios afetam a performance do indivíduo no outro; e (3) comportamento quando o comportamento no papel exercido em um dos domínios deixa a desejar em decorrência do papel no outro domínio.

Longenecker, Moore e Petty (1997) relatam que é permitida a possibilidade de compreender e conviver bem com o fundamento que difere duas esferas: a família - com a função primária de cuidado e proteção de seus membros, tem como objetivo o pleno desenvolvimento de cada um de seus membros, além de promover recompensas iguais, independente de suas limitações e capacidades; e a empresa volta sua atenção para a produção, distribuição de bens e/ou serviços com objetivo de obter lucro e sobreviver.

Na iminência de conflitos em empresas familiares, espera-se do pai-fundador a tarefa de intervir e conciliar as partes, fazendo com que a situação seja amenizada (MERHI et al., 2010). No entanto, segundo Oliveira (2006), muitas vezes os conflitos na empresa familiar se originam pelo próprio fundador, que pode ter dificuldades em aceitar opiniões e posições divergentes da sua própria, e considerar isso uma atitude normal, por ser a empresa uma extensão de si mesmo e um local para a sua realização profissional e pessoal.

Outro ponto é a qualidade da relação de trabalho entre pais e filhos dentro do universo da empresa familiar. Davis e Tagiuri (1989) dizem que em determinados momentos do ciclo de vida de cada um existe a tendência de uma melhor ou pior relação entre pais e filhos. A rivalidade entre sucessores, afirma Lodi (1987) ser outro problema, pois durante o conflito na empresa, perde-se tempo demasiado em hesitações, em procrastinações ou em tentativas frustradas de negociar o inegociável.

Gersick et al. (2006) revelam que o conflito não pode e nem deve ser evitado em uma empresa familiar, mas as fontes do mesmo devem ser diagnosticadas e tratadas como algo produtivo. Assim, a empresa familiar tem como desafio equacionar os diversos sistemas de interesses relacionados à família, à estrutura de propriedade e à estrutura de gestão, gerenciando interesses tanto de natureza coletivas quanto individuais. Conforme Moreira Júnior (2006), para que os conflitos dentro da organização sejam administrados dentro de um entendimento razoável, é necessário que as pessoas envolvidas no processo deem abertura e propiciem o diálogo, pois somente por meio deste comportamento serão abertos caminhos para uma convivência harmoniosa.

A gestão da empresa familiar que possui características diferenciadas pode ser considerada mais um foco de conflito. Dreher e Tomio (2004) afirmam que na gestão da empresa familiar muitas vezes os papéis na família e na empresa podem tornar-se confusos. Os problemas da empresa atravessam as paredes da casa e vice-versa, e a intimidade pode atrapalhar o comportamento empresarial. Possuir uma definição de responsabilidades minimiza os conflitos.

A profissionalização da gestão também é outro gerador de conflitos em empresas familiares. Para que uma empresa se torne profissional, o primeiro passo, afirma Ricca (2005), não é contratar administradores profissionais que não pertençam à família. $O$ fundamental é a atitude que a família assume diante da profissionalização.

Diversas ações praticadas pelos membros da família podem ser consideradas como desencadeadoras de conflitos. Uma delas, comum entre pai e filho, tem sua origem muito cedo, iniciada durante a fase da infância do herdeiro. Chamada de altruísmo, é a fase em que o pai passa a se preocupar com o bem-estar do filho antes do dele (SARDEMBERG, 2009). Becker (1981 apud SARDEMBERG, 2009, p. 5) argumentou ser comum uma geração que sacrifica gastos no presente, investindo na educação dos filhos na expectativa de que no longo prazo a renda familiar seja beneficiada.

Assim, o comportamento altruísta pode gerar total dependência dos filhos à generosidade de seus pais, fazendo com que eles esbanjem a riqueza na expectativa de que venham a ser resgatados 
quando precisarem (BERGSTROM, 1989). Explica Lubatkin et al. (2005) que também pode fazer emergir novos conflitos no contexto empresarial, a partir do momento em que o 'filho pródigo' compromete os ativos futuros de outros familiares que não apresentam o mesmo comportamento oportunista. Ou, ainda, quando o filho não corresponde às expectativas do pai, demonstrando falta de competência ou comprometimento com o futuro da empresa.

\section{METODOLOGIA}

O presente estudo caracteriza-se por ser de natureza qualitativa. Segundo Vieira (2004), a pesquisa qualitativa favorece a aproximação do investigador ao objeto pesquisado, garante a riqueza de dados, permite ver um fenômeno na sua totalidade, bem como facilita a exploração de contradições e paradoxos.

O método de pesquisa deste estudo é o estudo de casos múltiplos. Conforme Yin (2001), o estudo de caso apresenta-se como uma estratégia de pesquisa que tem por objetivo analisar profundamente uma unidade, uma vez que reúne, por meio de diferentes instrumentos de coleta de dados, um conjunto considerável de informações detalhadas. Yin (2001, p. 69) destaca ainda que, nos estudos de casos múltiplos, cada caso individualmente deve ser selecionado de forma que "permita prever resultados semelhantes, replicação literal, ou produzir resultados contrastantes, replicação teórica", em função do que foi previsto no início do estudo (YIN, 2001). Consequentemente, os resultados provenientes da aplicação de um estudo de casos múltiplos possuem maior credibilidade e são considerados mais convincentes, proporcionando ao pesquisador maior segurança para a exposição deles (YIN, 2001).

Yin (2001, p. 71) afirma que "qualquer aplicação da lógica de amostragem aos estudos de caso estaria mal direcionada", pois esses não se preocupam com a incidência dos fenômenos. A importância de realizar esta pesquisa como estudo de casos múltiplos parte da premissa de que existem poucos estudos no Brasil que analisam os conflitos nas empresas familiares, levando a acreditar que mais de uma empresa pesquisada poderia trazer informações complementares sobre o assunto ainda pouco explorado. O principal critério adotado para a escolha dos casos foi a acessibilidade a empresas cuja família estivesse na gestão do negócio, especialmente o fundador e pelo menos um herdeiro. Foram analisados quatro casos com essas características.

As entrevistas, para Yin (2001), constituem a principal fonte de evidência de um estudo de caso. Os dados deste estudo foram coletados por meio de entrevistas pessoais semiestruturadas com pelo menos um herdeiro de cada empresa, por meio de roteiro de entrevistas, e duração média de 1 hora e 05 minutos. Foram realizadas quatro entrevistas com os herdeiros das empresas analisadas. Vale destacar que não foram realizadas entrevistas com os fundadores, devido às dificuldades de acesso e alegação de falta de tempo para entrevistas. As entrevistas foram gravadas e, posteriormente, transcritas e analisadas com a adoção da técnica de análise de conteúdo, que visa captar as características essenciais, os significados, as convergências e as divergências dos conteúdos das entrevistas. Na presente investigação, foi utilizada a estratégia de emparelhamento, que conforme Laville e Dionne (1999), o pesquisador deve associar os dados coletados a um modelo teórico com o objetivo de compará-los. É necessário ter uma teoria sobre a qual o investigador vai se apoiar para imaginar um modelo do fenômeno ou da situação em estudo.

Yin (2001) explica que os resultados dos estudos de caso devem possuir validade de constructo, validade externa e interna, sendo que esta última é característica de estudos explanatórios, não se aplicando, portanto, a esta pesquisa, que pode ser classificada como exploratória-descritiva.

No que se refere à validade de constructo, Yin (2001) explica que ela está associada à determinação de medidas operacionais corretas para os conceitos estudados. Assim, visando assegurá-la, foram definidas as categorias analíticas do estudo com o intuito de saber exatamente o que se pretende estudar, que estão detalhadas no Quadro 01. A validade externa, por sua vez, busca estabelecer o domínio no qual as descobertas de um estudo podem ser generalizadas (YIN, 2001). No entanto, afirma esse autor, em estudos de casos essa generalizações são analíticas, não estatísticas. Na generalização analítica, o pesquisador está tentando generalizar um conjunto particular de resultados a alguma teoria mais abrangente, não está utilizando a lógica amostral. Nesse sentido, a validade externa deste estudo será obtida por meio da comparação dos resultados com a teoria existente, bem como por meio da lógica de replicação, que é obtida em estudos de caos múltiplos. 
Para facilitar a comparação das evidências empíricas com os preceitos teóricos, foram estabelecidas categorias analíticas a partir das abordagens teóricas balizadoras do estudo. O Quadro 01 apresenta as categorias analíticas e elementos de análise.

Quadro 01 - Categorias e Elementos de Análise

\begin{tabular}{|l|l|}
\hline CATEGORIAS ANALÍTICAS & ELEMENTOS DE ANÁLISE \\
\hline Processo de Sucessão & $\begin{array}{l}\text { Tempo do fundador na empresa } \\
\text { Definição sobre o processo de sucessão e o sucessor } \\
\text { Planejamento do processo sucessório } \\
\text { Existência de conflitos }\end{array}$ \\
\hline Conflitos & $\begin{array}{l}\text { Processo de tomada de decisão } \\
\text { Estratégias de crescimento } \\
\text { Gestão do negócio } \\
\text { Profissionalização da gestão } \\
\text { Outros conflitos }\end{array}$ \\
\hline
\end{tabular}

Elaborado pelos autores (2012)

\section{DESCRIÇÃO E ANÁLISE DOS CASOS}

A seguir, cada caso é descrito e também analisado com base nas categorias analíticas detalhadas no Quadro 01.

\section{Caso 01}

A empresa de material de construção foi criada em abril de 2003, devido a uma série de demissões que ocorreram em empresa de telecomunicação em Sergipe. O empresário foi demitido e resolveu investir em um sonho, o de ter um negócio próprio. Atualmente, a empresa possui 11 funcionários, e os membros da família que trabalham na empresa são pai, mãe e filho, respectivamente, sócio/ gerente, caixa, e sócio/gerente. O fundador tem 57 anos, possui curso superior em teologia e é técnico na área de telecomunicações, é sócio/gerente da empresa, e está no comando dela desde o início. Já o herdeiro possui 22 anos, é estudante do curso de administração e atua como sócio/ gerente, assim como seu pai. Formalmente está na empresa desde 2008, mas sempre ajudou na empresa, tornando-se um assessor, pois sempre trabalhou na loja, seja nas férias escolares, ou ajudava quando seu pai ou sua mãe precisavam sair para resolver problemas externos.

O herdeiro afirmou que provavelmente será ele o sucessor, apesar de não ter ocorrido a escolha formal do sucessor ainda, visto que suas irmãs não estão engajadas com o negócio, não havendo conflitos na escolha do sucessor. O sucessor é o único filho homem da família. Ele revelou, ainda, que seu pai já avisou quando deixará a gestão negócio, o mesmo acontecendo com sua mãe.

\footnotetext{
"Eu tenho mais duas irmãs, mas elas estão engajadas em outras áreas, um na de saúde, a outra na de humanas. Provavelmente e futuramente vai ser tocado por mim, eu vou ocupar as funções que meu pai ocupa hoje e vou procurar alguém para as que ocupo hoje, só que agregando um pouco mais.[...] Meu já pai disse que quando minha irmã mais nova se formar vai querer se aposentar, até lá vou trabalhar junto com ele. E minha mãe disse que tá saindo próximo ano. [..] Meu pai gosta muito da empresa, ele nunca pensou em passar para alguém fora da família. Acho que ele tem o sonho de passar para mim mesmo."
} 
As principais decisões da empresa são tomadas em conjunto, mas cada um responsável por determinada função, sendo um pela frente de loja, o pai, e outro pela compra/venda, o entrevistado. Sobre a geração de conflitos nesta atividade, ele destaca que houve épocas em que os conflitos eram mais frequentes, mas que agora as coisas melhoraram e está aprendendo a trabalhar com o pai. Os conflitos gerados na tomada de decisão referem-se ao estilo centralizador do pai, e a intolerância que o filho apresenta quando o fundador tomando a frente de seu papel.

A percepção do herdeiro sobre as decisões tomadas pelo fundador muitas vezes são boas, mas, em muitos casos, ele acaba discordando. Ele alega que seu pai faz muitas coisas sem planejamento, age por impulso quando vê algo errado, agindo de forma diferente da sua, pois gosta de pensar mais. Esta impulsividade do fundador incomoda o herdeiro, visto que ele acredita que poderia ter acrescentado algo, tanto pelo seu estudo, quanto por seu senso crítico de administrador. Já sobre a percepção do fundador sobre as suas decisões, o herdeiro declara que seu pai o acha precipitado, e que não tem medo de correr risco, nem que algo dê errado. Outro ponto que o fundador discorda do herdeiro é com relação à liberdade de horário do filho, pois crê que este deveria dar o exemplo e cumprir horários mais rígidos, como se fosse qualquer empregado.

No que tange as ideias trazidas pelo herdeiro para implementar o negócio, elas são bem aceitas, mesmo que algumas não considere boa. $O$ herdeiro afirma que seu pai o respeita muito, mas considera que a ideia não é boa, acaba não querendo ouvir, o que o irrita um pouco. Porém o entrevistado também revela ser um pouco intolerante, principalmente quando o pai tenta tomar a frente de suas atividades, talvez devido à iminente perda do comando da empresa.

Quando o assunto é o contrário, a aceitação do herdeiro das ideias novas sugeridas pelo fundador, o entrevistado revela que há barreiras, conforme explica:

\footnotetext{
"Eu acho que ele aceita mais do que eu. Eu acho que eu acabo tendo mais barreiras, eu tenho engajado muito essa coisa do negócio já ser meu, e não pensar muito em conjunto às vezes. Mas eu não faço isso por ser chato, faço por necessidade, principalmente porque às vezes ele tem uma ideia e começa a fazer e não me comunica, não pede minha opinião, e eu sei que poderia ajudar de alguma forma."
}

A responsabilidade pelas estratégias de crescimento da empresa fica a cargo do fundador e do herdeiro, mas existem divergências sobre quais rumos o negócio deve tomar. De acordo com o herdeiro, o fundador pensa em diversificar a loja, direcioná-la para algo mais ligado à decoração, enquanto que ele pensa em continuar na mesma linha de produto, só que aumentando sua presença na cidade. $O$ herdeiro revela ainda que esta discussão nunca aconteceu e nunca atrapalhou o andamento da empresa, mas que em breve virá à tona.

Foi visto que as decisões sobre contratação, treinamento, demissão e salário concentram-se nas mãos do fundador, mas com a participação do herdeiro. O entrevistado afirma haver divergências na opinião entre ele e seu pai, pois o fundador é mais conservador, voltado para os custos; enquanto que ele está numa visão mais moderna da administração, focando o melhor para os funcionários e para a sociedade.

Referente à gestão financeira, o responsável também é o fundador. O herdeiro destaca que precisa consultá-lo para saber se pode investir ou não. No entanto, revela que tem acesso a tudo, as opiniões são compartilhadas, apesar de a decisão final ser do fundador. Em relação à profissionalização da gestão, o herdeiro afirmou que pretende profissionalizar a gestão da empresa e acha fundamental a presença de um administrador. Ele afirma ainda ter planos para o futuro investir em profissionais para empresa, mas no momento, por considerar a empresa pequena, não é possível.

O herdeiro foi perguntado de que forma seu papel na família atrapalha no seu trabalho, e o mesmo relata que esta relação atrapalha o seu trabalho quando começa a misturar trabalho com questões familiares. Sobre como seu papel no trabalho atrapalha nas relações familiares, o herdeiro destaca que questões como o lazer em família são as que mais sofrem, mas que o apoio e a confiança recebidos são pontos relevantes.

Os principais conflitos entre o herdeiro e o fundador giram em torno da personalidade centralizadora do pai e 'delegadora' do filho. Além disso, conflitos existem com relação ao estilo de gerenciar, o pai voltado aos custos, e o filho alega que possui abordagem mais humanística. O entrevistado diz que estes conflitos são resolvidos na base da conversa, mas muitas vezes os argumentos não estão bem fundados, o que atrapalha a relação: 
"A gente conversa, troca opiniões. O problema é que muitas delas não são bem fundamentas, e acabam caindo na relação pai e filho. Não passando de um comentário de um filho resmungão e um pai controlador. Mas a gente respeita muito um ao outro."

Questionado sobre entre quais membros da família costuma-se ter mais conflitos, o entrevistado afirma ser sazonal, em que houve períodos que era mais com sua mãe e outros com seu pai, mas salienta que a grande parte é entre o fundador e o herdeiro. E para resolver estas divergências, o herdeiro revelou que, assim como seu pai, procura ser o mais profissional possível.

\section{Caso 02}

Com apenas 6 anos de fundada, a empresa é do ramo da construção civil, conta com 45 funcionários e três membros no negócio da família, o pai, sócio/diretor geral; a mãe, que cuida parte financeira; e o filho, sócio/estagiário. O principal motivo para a criação foi para ser uma sociedade entre pai e filho, visto que seu avô possui uma empresa no mesmo ramo. O fundador é graduado em engenharia civil e com 53 anos, o fundador da empresa ocupa do cargo de diretor geral, e está na empresa desde o início. $O$ herdeiro parece ter trilhado os caminhos do pai, visto que é estudante de engenharia civil, possui 22 anos, está na empresa desde 2008 e ocupa o cargo de estagiário. 0 herdeiro é o único filho e tem uma irmã. Quanto ao processo de sucessão, o herdeiro revela que não houve e que ainda não foi escolhido o sucessor do negócio, contudo ele e a irmã são os herdeiros do negócio e ela não demonstra interesse na empresa.

Percebeu-se que as decisões mais importantes da empresa, segundo o herdeiro, quem toma é o fundador, que decide tudo que envolve riscos maiores, principalmente no que tange a parte financeira. No entanto, se for algo simples ou imediato, o herdeiro tem liberdade para decidir. Contudo, ele revela que a maioria das decisões costuma ser compartilhada. Esse processo de tomada de decisão não tem gerado conflitos entre fundador e herdeiro. O entrevistado apoia-se na experiência do pai, procurando ouvir a opinião dele sobre suas decisões, e quando não concorda com a sua visão, explica o porquê das suas decisões, que, às vezes, é entendida e, em outras, não.

No que tange a percepção do herdeiro sobre as decisões tomadas pelo fundador, ele acha assertiva, no geral. Revela que em algumas não concorda, e diz que o pai precisa se atualizar um pouco mais. O fundador, segundo o herdeiro, acredita que suas decisões são modernas, rápidas e diferentes, sendo que algumas ele considera acertada e outras não. Já em relação às ideias trazidas pelo herdeiro para implementar o negócio, o herdeiro confessa que algumas são barradas; e que aceita a maioria das ideias novas sugeridas pelo fundador, e que elas geralmente estão relacionadas à parte técnica das obras de construção.

Em relação às estratégias de crescimento da empresa, são responsáveis o herdeiro, o pai e a mãe. De acordo com o herdeiro, um não faz nada importante sem comunicar ao outro. No tocante às diferentes percepções entre o herdeiro e o fundador, de quais rumos o negócio deve tomar, hoje isto não ocorre mais. Quando o assunto é contratação, treinamento, demissão e salário, o fundador é quem é responsável, porém o herdeiro opina sempre, não havendo conflitos nestes aspectos. Sobre o estilo de gestão de pessoas, o entrevistado considera o pai muito maleável, o que atrapalha o andamento das atividades algumas vezes, principalmente nas obras.

Quanto à gestão financeira, quem é responsável é a mãe do herdeiro, com a supervisão do fundador. O herdeiro não se envolve muito nesse aspecto. Perguntado se pretende profissionalizar a gestão da empresa, o herdeiro afirma que sim, mas futuramente, e que o fundador concorda com a sua opinião. Para o herdeiro, possuir uma gestão profissional, com pessoas competentes para desenvolver tal atividade é fundamental, não importando se esta é ou não da família. Sobre a possível obrigatoriedade de contratar um administrador para a empresa, o entrevistado julga realmente necessário, visto que traria novos conhecimentos para a empresa.

Quanto a outros conflitos, se o seu papel na família atrapalha no seu trabalho, o herdeiro explicou que, às vezes, não existe separação entre casa e trabalho, o que pode prejudicar um pouco:

\footnotetext{
"Às vezes as cobranças de casa são trazidas para a empresa, e este intermédio não é bom, é preciso aprender a separar uma coisa da outra. E ajuda pela afinidade, pois você tem mais liberdade para discutir algumas coisas que não faria se não fosse da família."
} 
Sobre os principais conflitos entre o fundador e o herdeiro, o entrevistado revela que é referente à gestão de pessoas e questões relacionadas à diferença de gerações:

"Gestão de pessoas mesmo, e algumas decisões que vem de cunho da geração mesmo, eu tenho uma visão um pouco diferente dele, muito por causa da idade, mas nada grave. Ele é mais conservador que eu, como já disse devido sermos de gerações diferentes."

Ele revela que há conflitos entres os três membros da família, mas que é mais frequente entre ele e o pai, e que ambos procuram argumentar e tentar entrar em consenso.

\section{Caso 03}

Fundada em 2002, a empresa atua no ramo de limpeza predial e serviços gerais. Seu quadro funcional é de 297 funcionários. Hoje há três membros da família na gestão do negócio, o pai e dois filhos, sendo um do sexo feminino e outro do masculino. O pai, além de fundador da empresa, é o diretor; a filha é gerente financeira e administrativa e o filho é o auxiliar comercial. Para este caso, foi entrevistada a filha do fundador. Sobre a criação do negócio, ela revela que o pai contou com sorte, não dele, a de um amigo:

\footnotetext{
"Meu pai trabalha em uma empresa que fazia licitações para a Petrobrás. Ele sempre teve vontade de ter o seu negócio, mas nunca conseguia por causa do capital. Certo dia, um amigo dele, muito sortudo por sinal, ganhou na loteria e o convidou para abrir uma empresa, investindo boa parte do capital. Assim que teve a oportunidade concreta de abrir a empresa, ele largou o emprego e colocou todos os seus esforços no empreendimento. A sociedade, porém, após algum tempo foi desfeita."
}

O fundador da empresa tem 46 anos, é formado em técnico agrícola, é o diretor geral da empresa, e está desde a fundação à frente do negócio. A herdeira possui 23 anos, é formada em administração e faz pós-graduação em finanças. Está na empresa desde 2009 e ocupa o cargo de gerente financeira e administrativa. Há também outro herdeiro na empresa, o filho mais novo, que ocupa o cargo de assistente administrativo.

Em se tratando do processo sucessório, este ainda não aconteceu e segundo a herdeira não acontecerá tão cedo, pois o fundador já revelou que quer envelhecer trabalhando. Além dela, o irmão mais novo também trabalha na empresa, porém há menos tempo que ela. Sobre sua continuação na empresa, ela revela sua indecisão, principalmente por causa remuneração e, caso recebesse uma proposta interessante, deixaria a empresa, mas em momento algum pararia de ajudar seu pai e seu irmão nas operações do negócio.

Quanto às decisões mais importantes da empresa, estas ficam sob a responsabilidade do fundador. Segunda a herdeira, ele é quem decide sobre financiamento, demissões de pessoas, crescimento da empresa e outras questões estratégicas. Contudo, ela destaca que costuma, muitas vezes, comunicar sua decisão e, às vezes, pedir sua opinião. A herdeira considera que as decisões tomadas pelo fundador são embasadas no fato de ele possuir muito conhecimento na área. Já a percepção do fundador sobre suas decisões ela considera que no geral as consideram boas, mesmo não concordando com algumas.

No que se refere às ideias trazidas pela herdeira para implementar no negócio, elas são bem aceitas pelo fundador, que apenas põe ressalvas se for preciso usar os recursos financeiros da empresa, cabendo à herdeira mostrar o custo benefício da implementação da ideia. No contrário, percebe-se uma maior aceitação, por considerar as ideias ótimas, principalmente para a parte operacional, visto que o fundador, dinâmico e prático, possui vasto conhecimento na área.

Referente a estratégias de crescimento da empresa, quem fica responsável por isso é o fundador, mas a herdeira afirma ajudá-lo no possível. E diz ainda que não há divergências de percepções sobre o rumo que o negócio deve tomar. Sobre contratação, treinamento, demissão e salário, atividades da gestão de pessoas, quem fica responsável é o fundador e, segundo a herdeira, não há divergência neste aspecto. Quanto à gestão financeira, a responsável é a entrevistada que revela que as opiniões são compartilhadas com o fundador.

No que tange a pretensão de se profissionalizar a gestão da empresa, a herdeira revela que sim. Ela diz ainda que é totalmente a favor de se contratar um administrador para empresa, não só ela, 
mas o pai também. Segundo a herdeira, profissionalizar a gestão é uma necessidade e um meio de melhorarem suas atividades, ainda mais pela pretensão do fundador de abrir outras empresas.

Perguntada sobre de que forma seu papel na família atrapalha no seu trabalho, ela retoma a questão financeira, sendo enfática:

\begin{abstract}
"Eu trabalho mais que um funcionário normal, minha remuneração é menor que em outras empresas. Ele acha que porque eu sou filha ele me paga o quer. Atrapalha quando não há a separação de filha e empregada."
\end{abstract}

Sobre como seu papal no trabalho atrapalha nas relações familiares, ela cita que ajuda devido à facilidade de conversar e dar sua opinião. Em contrapartida atrapalha, pois como funcionária ela não pode, nem deve, dar explicações a terceiros sobre a vida pessoal de seu pai, mesmo que os questionadores sejam familiares.

Em relação aos conflitos existentes entre ela o fundador, argumenta que no início eram mais frequentes, mas hoje não há muitos conflitos. A herdeira fala que o momento em que a gestão familiar na empresa gera conflitos no negócio e no convívio da família acontece quando algum membro quer ter tratamento especial por fazer parte da família. Já em relação ao momento em que o convívio familiar gera conflitos no negócio e na gestão da empresa, ela revela que só em casos de discussões pesadas em casa, deixando um clima estranho na empresa.

A entrevistada ainda revela que não há muitos conflitos entre os membros da família. Ela alega que cada um sabe o que tem que fazer, e que as ideias que antes não eram consideradas pelo pai, hoje são bem aceitas, pois eles conversam e resolvem conflitos que possa estar atrapalhando o trabalho.

\title{
Caso 04
}

Com 380 funcionários, a empresa deste caso é do ramo de engenharia civil e encontra-se no mercado desde 1985. Atualmente, pai, mãe e filho participam da gestão da empresa, como sócio/ presidente, sócia/presidente e gerente de vendas imobiliário, respectivamente. O herdeiro destaca que seu pai sempre teve o sonho de ter um negócio, uma construtora e, quando surgiu a oportunidade, iniciou o negócio. Quando começou, era apenas ele e alguns pedreiros, e hoje conta com mais de 300 funcionários. O herdeiro conta que seu pai trabalhava numa empresa de obras públicas desde 1970 , e sempre trabalhou com licitações de terrenos. Foi quando surgiu a oportunidade de abrir a empresa, em 1985, ele teve a ideia e estava com capital suficiente. Decidiu abrir sozinho, focando em obras públicas, já que tinha conhecimento da área e possuía alguns contatos. Isso durou até 1995, ou seja, foram 10 anos com este foco do negócio. A partir daí, resolveu investir no mercado mercado privado, com vendas de apartamentos, casas e prédios.

O fundador da empresa possui 57 anos é formado em engenharia civil, atua como presidente da empresa e está na gestão da mesma desde o início. Já o herdeiro tem 22 anos, estuda administração, está na empresa desde 2006 e ocupa o cargo de gerente de vendas imobiliário.

Em relação ao processo de sucessão, este ainda não ocorreu, segundo o herdeiro os sucessores serão ele e seu irmão mais velho, como comenta:

\footnotetext{
"Provavelmente eu e meu irmão, pois minha irmã não se envolve muito não. Meu irmão é formado em Eng. Civil e está fazendo Pós em outro estado, mas provavelmente quando ele terminar ele volta para trabalhar com a gente."
}

Quanto às decisões mais importantes, o fundador é quem as toma, sempre com o auxílio dos gerentes. As decisões costumam ser tomadas por ele, mas ele procura deixar o herdeiro informado das mais importantes. O entrevistado afirma não procurar se envolver tanto no processo de tomada de decisão, talvez por isso não haja conflitos. O herdeiro ainda considera as decisões tomadas pelo pai corretas. Segundo o herdeiro, o fundador concorda com a maioria das suas decisões, e quando discorda, procura conversar e explicar o porquê. O entrevistado revela ainda que, quando o fundador percebe que o trabalho do filho não está indo de acordo com o esperado, ele manda refazer e que o cobra mais de que um funcionário.

Em relação às ideias trazidas pelo herdeiro para implementar no negócio, o herdeiro afirma que o fundador é aberto, porém não gosta muito de inovações. 
Referente a estratégias de crescimento da empresa, quem é responsável é o fundador. O herdeiro afirma ainda não haver diferentes percepções sobre os rumos de negócio deve tomar, pois pensa de forma igual o crescimento da empresa, mas com a devida estrutura. No tocante às atividades de gestão de pessoas, tais como contratação, treinamento, demissão e salário, quem fica responsável é setor de pessoal, o fundador apenas dá o aval final. Sobre o tratamento com os funcionários, o entrevistado diz que seu pai o faz da melhor maneira, mas destaca a sua falta de tempo. Quanto à gestão financeira, também há um setor responsável, em que o fundador apenas dá aval do que é apresentado. O herdeiro revela que quase nunca opina ou lhe é compartilhado algo a respeito, apenas se algo muito importante ocorre.

Questionado sobre a profissionalização da gestão, o herdeiro revelou que a empresa já possui uma gestão profissionalizada, pois possui alguns gerentes. Sobre a possível obrigatoriedade de contratar um administrador para assumir empresa, ele disse que não acha necessário, mas que não enxerga problemas com isso. O herdeiro revelou ainda que o fundador provavelmente terá uma visão parecida com a sua, mas que vai preferir por alguém da família que possua os conhecimentos necessários, por questão de confiança e segurança.

Questionado sobre como seu papel na família atrapalha no seu trabalho, o entrevistado disse que ajuda, mas que há coisas que precisam ser evitadas:

"Ajuda em relação ao trabalho é bom porque a gente pode ter mais acesso um ao outro, e pode discutir mais sobre o que tá acontecendo. Às vezes coisas que não nada a ver com o trabalho eu acabo falando. Não que chegue a atrapalhar, mas é chato, é melhor evitar."

Questionado sobre como seu papel no trabalho atrapalha as relações na família, ele diz que discussões que eram para serem feitas na empresa são levadas para casa, mas que isso não gera problemas, como explica:

\footnotetext{
"Eu acho não, apenas em momentos quando você fala coisas de casa na empresa, e em casa coisas da empresa. Meu pai sempre teve um bom relacionamento com a gente, então isto facilita a gestão."
}

Já o momento em que o convívio familiar gera conflitos no negócio e na gestão da empresa, o entrevistado aponta que não há, pois ele o trata com maior cobrança de qualquer funcionário:

"Aqui ele me trata como qualquer funcionário. Ele me cobra, me dá bronca, até mais que os outros. Muita gente acha que trabalhar com o pai é bom, acham que será moleza. Eu acho que não, ele cobra duas vezes mais que se fosse outra pessoa. O fato de eu ser filho não influencia não."

Os principais conflitos que acontecem entre o herdeiro e o fundador referem-se a ideias inovadoras. Eles procuram sempre entrar em um consenso, mas a decisão final é sempre do fundador.

\section{ANÁLISE COMPARATIVA DOS CASOS}

Após a descrição dos casos, procede-se à análise comparativa dos quatro casos, conforme as categorias analíticas e os elementos de análise estabelecidos na metodologia e utilizados nas descrições dos casos. Nessa análise comparativa, buscou-se enfatizar as semelhanças e as diferenças mais significativas entre as percepções herdeiros nos casos. Além disso, procurou-se, sempre que possível, comparar os resultados deste estudo com a base teórica, em busca da generalização analítica (YIN, 2001).

Inicialmente, será apresentada a caracterização das empresas analisadas no Quadro 02 . São empresas de pequeno e médio porte, de setores de comércio, serviço e construção civil.

Quadro 02 - Caracterização das empresas

\begin{tabular}{|l|l|}
\hline Caso & Caracterização das Empresas \\
\hline Caso 01 & $\begin{array}{l}\text { A empresa, atuante no ramo de material de construção, foi fundada em 2003, possui } 11 \\
\text { funcionários e } 3 \text { membros da família na empresa, fundador, fundadora e herdeiro. }\end{array}$ \\
\hline Caso 02 & $\begin{array}{l}\text { Empresa do ramo da construção civil, fundada em 2006, com } 45 \text { empregados e } 3 \text { membros } \\
\text { da família no negócio, fundador, fundadora e herdeiro. }\end{array}$ \\
\hline
\end{tabular}




\begin{tabular}{|l|l|}
\hline Caso 03 & $\begin{array}{l}\text { Fundada em 2002, a empresa do ramo da prestação de serviços de limpeza, possui } 297 \\
\text { empregados, e } 3 \text { membros da família na empresa, fundador, herdeira e herdeiro. }\end{array}$ \\
\hline Caso 04 & $\begin{array}{l}\text { Com } 380 \text { empregados, fundada em } 1985 \text { e atuante no ramo da construção civil, a empresa } \\
\text { possui } 3 \text { membros da família, fundador, fundadora e herdeiro. }\end{array}$ \\
\hline
\end{tabular}

Nota-se que essas empresas já podem ser consideradas de sucesso, pois, segundo Oliveira (2006), a vida média das empresas familiares é de 9 anos. Gersick et al. (2006) afirmam que 60\% das empresas fracassam em menos de dois anos e $90 \%$ até o final do décimo ano.

A seguir, é apresentado no Quadro 03 o perfil dos fundadores, cujas informações foram dadas pelos herdeiros entrevistados. Os fundadores, com apenas uma exceção, são graduados e o mais jovem tem 46 anos.

Quadro 03 - Perfil dos fundadores

\begin{tabular}{|l|l|}
\hline Caso & Perfil dos Fundadores \\
\hline Caso 01 & $\begin{array}{l}\text { O fundador, o pai, possui o ensino superior, está empresa desde o início, ocupa a posição } \\
\text { de gerente e tem } 57 \text { anos. }\end{array}$ \\
\hline Caso 02 & $\begin{array}{l}\text { Engenheiro civil, com } 53 \text { anos, ocupa o cargo de diretor geral e está empresa desde o } \\
\text { início. }\end{array}$ \\
\hline Caso 03 & $\begin{array}{l}\text { O fundador tem } 46 \text { anos, é formado em técnico agrícola, atualmente é diretor geral da } \\
\text { empresa e está desde o início na mesma. }\end{array}$ \\
\hline Caso 04 & $\begin{array}{l}\text { Formado em engenharia civil, o fundador possui } 57 \text { anos, é diretor da empresa, e está na } \\
\text { mesma desde o início. }\end{array}$ \\
\hline
\end{tabular}

A seguir, o Quadro 04 traz o perfil dos herdeiros entrevistados, com uma exceção, são estudantes do curso de administração, muitos jovens com 22 e 23 anos de idade, ocupando posições de gerente ou estagiário.

Quadro 04 - Perfil dos herdeiros entrevistados

\begin{tabular}{|l|l|}
\hline Caso & Perfil dos Herdeiros \\
\hline Caso 01 & $\begin{array}{l}\text { É estudante de administração, do sexo masculino, tem } 22 \text { anos, está na empresa, formal- } \\
\text { mente, desde 2008, e também ocupa a posição de gerente. }\end{array}$ \\
\hline Caso 02 & $\begin{array}{l}\text { É estudante de engenharia civil, do sexo masculino, tem } 22 \text { anos, está na empresa desde } \\
\text { 2008, e também ocupa a posição de estagiário. }\end{array}$ \\
\hline Caso 03 & $\begin{array}{l}\text { É graduada em administração, tem } 23 \text { anos, ocupa o cargo de gerente administrativo/ } \\
\text { financeiro, e está desde } 2009 \text { na empresa. }\end{array}$ \\
\hline Caso 04 & $\begin{array}{l}\text { É estudante de administração, do sexo masculino, tem } 22 \text { anos, está na empresa desde } \\
\text { 2006, e também ocupa a posição de gerente de vendas. }\end{array}$ \\
\hline
\end{tabular}

Quando se analisa a primeira categoria, o processo de sucessão, observa-se no Quadro 05 que, com uma exceção, ainda não ocorreu, que não existe planejamento para a sucessão. No único caso da empresa 01, essa sucessão ocorre de forma planejada, e não ocorrem conflitos. Bernhoeft (1989) diz que a sucessão deve ser encarada como um processo que pressupõe a definição de atividades programadas e temporais, bem como a delimitação clara de papéis para as diferentes partes envolvidas. Garcia (2001) complementa dizendo que a falta de planejamento para o processo sucessório é o aspecto negativo mais recorrente de uma empresa familiar. Por sua vez, Brockhaus (2004) afirma que os critérios para a seleção de sucessores estariam relacionados com sua formação profissional, suas habilidades técnicas e gerenciais, bem como a intenção dos 
sucessores em participar da empresa familiar. É possível dizer que, para a escolha do sucessor, nos casos estudados, foram consideradas a formação profissional e a intenção de participar da empresa. A escolha do primogênito como sucessor dá-se em grande parte das famílias empresárias, segundo Gersick et al. (2006). Merhi et al. (2010) ressalta que esta acaba sendo a opção mais comum e automática aplicada para a escolha do sucessor.

Quadro 05 - Processo de Sucessão

\begin{tabular}{|l|l|}
\hline Caso & Processo de sucessão \\
\hline Caso 01 & $\begin{array}{l}\text { Está acontecendo de forma planejada, sendo o herdeiro entrevistado o sucessor, não } \\
\text { ocorrendo conflitos. }\end{array}$ \\
\hline Caso 02 & Não ocorreu, nem se planejou ainda. Possivelmente o herdeiro entrevistado será o sucessor. \\
\hline Caso 03 & Não ocorreu, nem se planejou ainda. Possivelmente o herdeiro assumirá a empresa. \\
\hline Caso 04 & Não ocorreu, nem se planejou ainda. Possivelmente o herdeiro assumirá a empresa. \\
\hline
\end{tabular}

O primeiro conflito analisado foi o processo de tomada de decisão. O Quadro 06 mostra comparativamente como esse processo ocorreu nas quatro empresas analisadas. Nota-se que quem toma as decisões mais importantes da empresa são os fundadores, mas em alguns casos o herdeiro participa da decisão. Já em relação à percepção do herdeiro sobre estas decisões, há consenso entre os herdeiros que elas são boas e assertivas.

No tocante às ideias trazidas para implementar no negócio, em ambos os lados, fundador e herdeiro, há aceitação. Eles sempre conversam, avaliam o que poderiam dar certo e implementam aquelas que foram aprovadas. Quanto aos conflitos, estes podem ser com relação a prioridades das ideias sugeridas, mas principalmente está na tomada de decisão do herdeiro.

Quadro 06 - Processo de tomada de decisão

\begin{tabular}{|l|l|}
\hline Caso & Processo de tomada de decisão \\
\hline Caso 01 & $\begin{array}{l}\text { As decisões são tomadas em conjunto entre o fundador e o herdeiro. As tomadas pelo } \\
\text { fundador são tidas como boas pelo herdeiro, apesar de o mesmo não concordar com algu- } \\
\text { mas. Já o fundador respeita as decisões do herdeiro, mesmo o considerando precipitado } \\
\text { em alguns casos. Quanto à aceitação das ideias trazidas, o herdeiro afirma que não há } \\
\text { barreiras, mas diz que o fundador aceita mais que o contrário. E os conflitos são decor- } \\
\text { rentes sobre qual rumo os negócios devem tomar. }\end{array}$ \\
\hline Caso 02 & $\begin{array}{l}\text { As decisões são tomadas pelo fundador, e o herdeiro as considera assertivas. Do contrário, } \\
\text { o fundador considera as tomadas pelo herdeiro modernas. Quanto às ideias, estas são tes- } \\
\text { tadas antes de serem difundidas, e aqui reside a raiz dos principais conflitos de ideias. }\end{array}$ \\
\hline Caso 03 & $\begin{array}{l}\text { As decisões são tomadas pelo fundador e o herdeiro as considera corretas. Do contrário, } \\
\text { o fundador considera as tomadas pelo herdeiro boas, apesar de não concordar com algu- } \\
\text { mas. Quanto às ideias, só há ressalvas quando é o herdeiro quem traz, e estas envolvem } \\
\text { investimento financeiro. E não há muitos conflitos. }\end{array}$ \\
\hline Caso 04 & $\begin{array}{l}\text { As decisões são tomadas pelo fundador e o herdeiro as considera ideais. Do contrário, o fun- } \\
\text { dador considera as tomadas pelo herdeiro boas, apesar de não concordar em alguns casos. } \\
\text { Quanto às ideias, não há barreiras nas trazidas pelo herdeiro. Não há muitos conflitos. }\end{array}$ \\
\hline
\end{tabular}

O segundo conflito analisado nas quatro empresas foi com relação à gestão de pessoas e financeira, que estão resumidos no Quadro 07. Observa-se que contratação, demissão e treinamento nas empresas pesquisadas ficam a cargo do fundador e que em apenas um caso já se encontra gerenciado por profissionais. É visto que em quase todos os casos não há conflitos, contudo, em um dos casos, há conflito relacionado ao tratamento que o fundador dispensa aos funcionários, em que é apontado que há demasiada flexibilidade. Na gestão de finanças das empresas pesquisadas, há mais participação dos envolvidos, talvez por isso ocorram poucos conflitos. 
Quadro 07 - Gestão de pessoas e financeira

\begin{tabular}{|l|l|}
\hline Caso & Gestão de pessoas, financeira \\
\hline Caso 01 & $\begin{array}{l}\text { O fundador é o responsável, mas o herdeiro participa. Não há conflitos no que tange a } \\
\text { gestão financeira, mas nas pessoas o herdeiro relata que ambos divergem na forma de } \\
\text { gerir suas equipes, gerando atritos algumas vezes. }\end{array}$ \\
\hline Caso 02 & $\begin{array}{l}\text { Quanto à gestão de pessoas, o fundador é o responsável, mas o herdeiro participa, não } \\
\text { havendo conflitos. No que tange a gestão financeira, esta fica sob responsabilidade da } \\
\text { mãe do herdeiro (fundadora), mas com supervisão do fundador. }\end{array}$ \\
\hline Caso 03 & $\begin{array}{l}\text { Quanto à gestão de pessoas, o fundador é o responsável, e não há conflitos. No que tange } \\
\text { a gestão financeira, esta fica sob responsabilidade da herdeira, mas com supervisão do } \\
\text { fundador, não ocorrendo conflitos. }\end{array}$ \\
\hline Caso 04 & $\begin{array}{l}\text { Estas atividades possuem gerentes responsáveis por cada uma, o fundador apenas su- } \\
\text { pervisiona. Não há conflitos. }\end{array}$ \\
\hline
\end{tabular}

Com relação aos conflitos decorrentes da profissionalização da gestão dos negócios, observase no Quadro 08 que nas quatro empresas não existem conflitos e que é vista como necessária. Esses achados são diferentes dos mencionados por autores como Ricca (2005), que apontam a profissionalização como foco de conflito entre fundador e herdeiro.

Quadro 08 - Profissionalização da gestão

\begin{tabular}{|c|c|}
\hline Caso & Profissionalização da gestão \\
\hline Caso 01 & $\begin{array}{l}\text { Julga necessária, e considera importante, mas tem receio devido a questōes financeiras. } \\
\text { Há conflitos neste aspecto, pois o pai considera a empresa pequena, não enxergando esta } \\
\text { necessidade. }\end{array}$ \\
\hline Caso 02 & Julga necessária, e tem planos para o futuro. Não há conflitos. \\
\hline Caso 03 & Julga necessária, e pensa na hipótese para o futuro. Não há conflitos. \\
\hline Caso 04 & Já possui uma gestão profissionalizada. Não há conflitos. \\
\hline
\end{tabular}

Finalmente, são apontados pelos entrevistados outros conflitos que estão resumidos no Quadro 09. Foi observado que, em apenas em um caso, o papel do herdeiro como filho atrapalha nas relações da família, pois o tratamento referente à salário e às cobranças é diferente dos demais funcionários. Os outros apenas alertam que só atrapalha quando os papéis de filho e empregado se misturam com as relações familiares e empresarial, mas caso isso não ocorra, ajuda, devido à proximidade, à confiança e à abertura para discussões.

Quadro 09 - Outros conflitos

\begin{tabular}{|l|l|}
\hline Caso & Outros conflitos \\
\hline Caso 01 & $\begin{array}{l}\text { No que tange ao seu papel nas relações trabalho/família, há prazer em trabalhar com a } \\
\text { família, e só atrapalha quando os papéis se misturam, havendo conflitos entre fundador e } \\
\text { herdeiro, devido às diferentes personalidades, ideias e decisões tomadas. }\end{array}$ \\
\hline Caso 02 & $\begin{array}{l}\text { No que tange ao seu papel nas relações trabalho/família, só atrapalha quando não há } \\
\text { separação dos papéis. Há maior incidência de conflito entre fundador e herdeiro, devido } \\
\text { às diferenças de gerações e forma de tratamento dos funcionários. }\end{array}$ \\
\hline Caso 03 & $\begin{array}{l}\text { No que tange ao seu papel nas relações trabalho/família, atrapalha, pois a herdeira não } \\
\text { recebe salário compatível com suas atividades, quando algum membro da família quer } \\
\text { ter regalias, e ainda o fato de perguntarem sobre a vida pessoal do fundador, seu pai. Os } \\
\text { conflitos, quando ocorrem, são entre herdeira e fundador, devido a ideias e tomadas de } \\
\text { decisões divergentes. }\end{array}$ \\
\hline
\end{tabular}


Beutell e Greenhaus (1985), assim como Carlson, Kacmar e Stepina (1995) sugerem que podem existir conflitos familiares ou no trabalho quando a atuação do indivíduo em um dos papéis dificulta o cumprimento das exigências do outro em função do tempo dedicado nas atribuições, da tensão provocada pela participação e dos comportamentos específicos exigidos por estes. Moreira Júnior (2006) aponta a comunicação entre as partes como a chave para a redução desses conflitos.

\section{CONCLUSÕES}

Pode-se afirmar que nos casos estudados o processo de sucessão encontra-se em andamento, em um dos casos com previsão para que o herdeiro assuma por completo as responsabilidades da empresa, nos outros está ocorrendo de maneira informal, de forma não planejada. Por se tratar de um processo em construção os fundadores estão testando seus futuros sucessores, que ainda jovens, já ocupam cargos de alta responsabilidade.

De forma geral, observou-se que, nos quatro casos, que não houve conflitos na escolha dos sucessores, e que é visível a intenção do herdeiro assumir a empresa. Brockhaus (2004) afirma que os critérios para a seleção de sucessores estariam relacionados com sua formação profissional, suas habilidades técnicas e gerenciais, bem como a intenção dos sucessores em participar da empresa familiar. Percebeu-se ainda que em três dos casos os herdeiros são os primogênitos, fato comum nas empresas familiares, como ressalta Gersick et al. (2006) e Merhi et al. (2010).

Referente ao processo de tomada de decisão e os conflitos decorrentes, nota-se que quem toma as decisões mais importantes da empresa ainda são os fundadores, mesmo que em alguns casos o herdeiro participe da decisão. Já em relação à percepção do herdeiro sobre estas decisões, há consenso entre os herdeiros que elas são corretas e ideias. Em relação à percepção dos herdeiros no que tange as decisões tomadas pelos fundadores, consideram que os fundadores tomam decisões algumas vezes precipitadas, mas, no geral, são consideradas boas.

No tocante às ideias trazidas para implementar no negócio, observou-se que os fundadores e os herdeiros sempre conversam, avaliam o que poderia dar certo e implementam as que foram aprovadas. Quanto aos conflitos existentes, verificou-se que aparecem principalmente de ordem financeira, mas foi revelado que há pouco ou quase nenhum conflito entre os herdeiros e os fundadores. Observou-se que contratação, demissão, treinamento e salário nas empresas pesquisadas ficam a cargo do fundador ou sob a responsabilidade do setor responsável.

Outro aspecto que merece destaque foi a profissionalização da gestão e os conflitos decorrentes desse processo. Observou-se que em todos os casos os herdeiros julgam necessário ou importante a profissionalização da gestão, sendo que em uma das empresas já se possui uma gestão profissionalizada. Foi observado também que nessas empresas se misturam as relações familiares e empresariais, devido à proximidade, à confiança e à abertura para discussões. Neste ponto, foi verificado que há uma diferença entre as empresas de maior e menor porte, sendo que a de maior porte já possui sua gestão profissionalizada.

Finalmente, pode-se dizer que as empresas precisam se preparar para a sucessão, visto que a maioria delas já possui um possível sucessor, evitando assim conflitos em um processo sem planejamento e informal. Sabe-se que as empresas que fazem uso de um processo planejado superam melhor as dificuldades e evitam problemas que comprometam a sobrevivência dos negócios.

\section{REFERÊNCIAS}

ALLIO, M. K. Family business: their virtues, vices, and strategic path. Strategy \& Leadership, v. 32, n.4, 2004, p. 24-33. 
BERGSTROM, T.C. A fresh look at the rotten kid theorem and other household mysteries. Journal of Political Economy, v. 97, pag. 1138-1159. 1989

BERNHOEFT, R. Empresa familiar: sucessão profissionalizada ou sobrevivência comprometida. São Paulo: Nobel, 1989.

BERTUCCI, J. L. de O. et al. Mecanismos de Governança e Processos de Sucessão: um estudo sobre a influência dos elementos da governança corporativa na orientação do processo sucessório em uma empresa familiar. São Paulo: FECAP, 2008. RBGN - Revista Brasileira de Gestão de Negócios. São Paulo, v. 11 , n. 31, p. 152-167, abr/jun 2008.

BEUREN, I. M.; MÜLER, E. T. C. Estrutura Formal e Práticas da Controladoria em Empresas Familiares Brasileiras. In: EGEPE, ENCONTRO DE ESTUDOS SOBRE EMPREENDEDORISMOE GESTÃO DE PEQUENAS EMPRESAS, 4., 2010, Recife. Anais... Recife, de 2010.

BEUTELL, N. J.; GREENHAUS, J. H. Sources of conflict between work and family roles. Academy of Management Review. v. 10, n. 1, p. 76-88, 1985.

BIEHL, K. A.; SILVEIRA, K. Análise de ações durante o processo sucessório de empresas familiares do cluster calçadista da região do Vale do Rio dos Sinos. In: EGEPE - ENCONTRO DE ESTUDOS SOBRE EMPREENDEDORISMO E GESTÃO DE PEQUENAS EMPRESAS. 3, 2003, Brasília. Anais... Brasília, 2003.

BORGES, A. F.; LIMA, J. B. A Construção do Processo de Sucessão Empreendedora em Empresas Familiares. In: Encontro da ANPAD, 33. 2009. São Paulo, SP, 19 a 23 de maio de 2009.

BORNHOLDT, W. Governança na empresa familiar: implementação e prática. Porto Alegre: Artmed Editora SA, 2005.

BRITO, M. J.; SILVA, S. S.; MUNIZ, M. M. J. . The Meanings of the Death of the Founder: The Constructionist Approach. BAR. Brazilian Administration Review, v. 7, p. 227-241, 2010.

BROCKHAUS, R. H. Family Business Successions: suggestions for future research. Family Business Review, v.17, n.2, p. 165-177, jun. 2004.

CAMPBELL, N.D.; HERIOT. K.C.; WELSH, D.H.B. The Black Box: Unraveling Family

Business Succession. New England Journal of Entrepreneurship, v.10, n. 2, 2007, p. 9-14.

CARLSON, D. S.; KACMAR, K. M.; STEPINA, L. P. An examination of two aspects of work-family conflict: time and identity. Women in Management Review. v. 10, n. 2, p. 17-25, 1995.

CANÇADO, V. L.; MUYLDER, C. F.; LIMA, J. B.; CASTANHEIRA, R. B. Ciclo Evolutivo e Sucessão em uma Empresa Familiar: um Estudo de Caso no Grupo Seculus. In: Encontro da ANPAD, 34, 2010, Rio de Janeiro. Anais... Rio de Janeiro, 2010.

CATTANI, M. A. Empresa Familiar: mandatos e mitos no comando de uma empresa. 1992. Dissertação (mestrado em administração). Departamento de Ciências Econômicas, UFRGS, Porto Alegre/RS.

COSTANZI, R. ; LANZANA, A. As empresas familiares brasileiras diante do atual panorama econômico mundial. São Paulo: Negócios Editora, 1999.

DAVIS, P. Realizing the potential of the family business. Organizational Dynamics, v. 5, n. 1, 1983, p.47-56.

DAVIS, J. A.; TAGIURI, R. The Influence of Life Stage on Father-Son Work Relationships in Family Companies. Family Business Review, vol. 2, n. 1, p. 47-74. Primavera de 1989.

DREHER, M. T.; TOMIO, D. GESTÃO DE EMPRESAS FAMILIARES NO TURISMO: A REALIDADE DE BLUMENAU, SC. Revista Eletrônica de Ciência Administrativa (RECADM) - ISSN 1677-7387 Faculdade Cenecista de Campo Largo - Coordenação do Curso de Administração v. 3, n. 2, nov./2004

DONNELEY, R.G. The family business. Harvard Business Review, Boston, v. 42, n. 4, p. 94-105, July/Aug. 1964.

DUARTE, F. D. Proposta para avaliação do processo sucessório em empresas familiares. - Porto Alegre. 2006. 135 f. Dissertação (Mestrado em Administração e Negócios) - Fac. De Administração, Contabilidade e Economia, PUCRS, Porto Alegre/RS. 
FOLLET, M. P. Profeta do gerenciamento. Rio de Janeiro: Qualitymark. 1997.

GARCIA, Volnei Pereira. Desenvolvimento das famílias empresárias. Rio de Janeiro: Qualitymark, 2001.

GERSICK, K. E., Davis, J. A., HAMPTON, M. M., LANSBERG, J. De geração para geração. Rio de Janeiro: Elsevier, 2006.

GRZESZCZESZYN, G.; MACHADO, H. V. Empresas familiares do setor moveleiro e desenvolvimento local em Guarapuava - PR. O\&S - Salvador, v.16 - n.51, p. 749-769 - Outubro/Dezembro - 2009.

GRZYBOVSKI, D.; TEDESCO, J. C.. Empresa Familiar X Competitividade: Tendências e Racionalidades em Conflito. Passo Fundo, 1998. Teor. Evid. Econ., Passo Fundo, v. 6, no 11, p. 37-68, nov. 1998.

HAVEMAN, H. A.; KHAIRE, M. V. Survival beyond succession? The contingent impact of founder succession on organizational failure. Journal of Business Venturing, v.19, n.3, p.437-463, mai 2004.

IBRAHIM, A.B.; ELLIS, W.H. Family business Management: concepts and practice. Kendall/Hunt Publishing Company, 2. ed, 2004, p.297-323.

KELM, M. L.; SCHORR, E. Mudança e Adaptação Estratégica numa Empresa Familiar: um Estudo de Caso no Ramo Supermercadista. In: Encontro da ANAPAD, 35. 2011, Rio de Janeiro. Anais... Rio de Janeiro, 2011.

KETS DE VRIES, M. The dynamic of family controlled firms: the good and the bad news. Organization Dynamics, v. winter, p. 59-71, 1993.

LAVILLE, C.; DIONNE, J. A construção do saber: manual de metodologia da pesquisa em ciências humanas. Porto Alegre: Editora Artes Médicas Sul Ltda.; Belo Horizonte: Editora UFMG, 1999.

LEONE, N. M. de C. P. G. O Saara não é um Deserto: O Processo Sucessório de suas Empresas é Repleto de Conhecimentos. In: EnANPAD - Encontro da ANPAD, 26, 2002, Salvador. Anais... Salvador, 2002.

LEONE, N. M. C. P. G. Sucessão na empresa familiar: preparando as mudanças para garantir sobrevivência no mercado globalizado. São Paulo: Atlas, 2005.

LESCURA, C.; BRITO, M. J.; CAPPELLE, M. C. A ; BORGES, C. A Dinâmica entre a Família e Organização: um Estudo de Caso utilizando o Método Historiográfico e a Técnica do Genograma. In: Encontro da ANPAD, 33. 2009, São Paulo. Anais... São Paulo, 2009.

LESCURA, C.; BRITO, M. J.; CAPPELLE, M. C. A. .A Dinâmica Entre Família e Organização: Representações Sociais Acerca das Relações de Parentesco em uma Organização Familiar. In: Encontro de Estudos Organizacionais da ANPAD, 6. 2010, Florianópolis. Anais... Florianópolis, 2010a

LESCURA, C.; MOREIRA, L. B.; BORGES, C. L. P.; CAPPELLE, M. C. A. Contradições da Herança: Reflexões teóricas acerca do conatus nas organizações familiares. In: Encontro da ANPAD, 34. 2010, Rio de Janeiro. Anais... Rio de Janeiro, 2010b

LITZ, R.A. Two sides of a one-sided phenomenon: conceptualizing the family business and business family as a möbius strip. Family Business Review, Boston, v. 21, n. 3, p. 217-236, Sept. 2008.

LODI, J. B. A empresa familiar. 4. ed. São Paulo: Pioneira, 1993.

LODI, J. B. Sucessão e conflito na empresa familiar. São Paulo: Pioneira, 1987.

LONGENECKER, J. G.; MOORE, C. W.; PETTY, J. W. Oportunidades em empresas familiares. In: LONGENECKER, J.G.; MOORE, C.W.; PETTY, J. W. Administração de pequenas empresas. São Paulo: Makron Books, 1997.

LUBATKIN, M.H. et al. The effects of parental altruism on the governance of family-managed firms. Journal of Organizational Behavior, v. 26, pag. 313-330. 2005.

MACEDO, José Ferreira de. Ciclo de Vida das Organizações e Transição de Liderança na Empresa Familiar. 2008. 152 f. Tese (Doutorado em Engenharia de Produção) - Programa de Pós-Graduação em Engenharia de Produção, Universidade Federal de Santa Catarina, Florianópolis/SC.

MACHADO, H. V. A identidade e o contexto organizacional: perspectivas de análise. Revista de Administração Contemporânea. Curitiba, Edição Especial, v. 51, n. 73, p. 51- 73, 2003. 
MERHI, D. Q.; SILVA JUNIOR, A.; SILVA, P. O. M.; SILVA, A. R. L. Carreiras e Processo Sucessório na Empresa Familiar: Uma Análise à Luz da Teoria Psicanalítica. In: Encontro da ANPAD, 34. 2010, Rio de Janeiro. Anais... Rio de Janeiro, 2010.

MILLER, D;STEIER,L;LE BRETON-MILLER,I. Lost in time: intergenerational succession, change and failure in family business. Journal of Business Venturing, v.18, n.4,2003, p.513-551.

MOREIRA JR., A. L. Estratégias de Governança na Empresa Familiar - Modelo para Redução de Conflitos Familiares e Perpetuação da Empresa. 2006. 131 f. Tese (Doutorado em Administração) - Universidade de São Paulo, São Paulo/SP.

MUSSI, F. B.; TEIXEIRA, R. M.; MASSUKADO, M. S. A EMPRESA FAMILIAR E A SUCESSÃO NA INTERPRETAÇÃO DO HERDEIRO. In: Encontro de Estudos Organizacionais da ANPAD, 5. 2008, Belo Horizonte. Anais... Belo Horizonte, 2008.

OLIVEIRA, D. P. R. Empresa Familiar: como fortalecer o empreendimento e otimizar o processo sucessório. São Paulo: Atlas, 1999.

OLIVEIRA, D. A empresa familiar: como fortalecer o empreendimento e otimizar o processo sucessório. São Paulo: Atlas, 2006.

PEISER, R.B; WOOTEN, L.M. Life-cycle changes in small family business. Business Horizons, v. 26, n. 3, May/June, 1983, p. 56-65.

PUGA, J. L. G. L. S. de. O Processo de Emergência de Estratégias em Empresas Familiares. 2006. 105p. (Dissertação, Mestrado em Psicologia Social e da Personalidade) - Pontifícia Universidade Católica do Rio Grande do Sul, Porto Alegre/RS.

ROBBINS, S. P. Comportamento organizacional. São Paulo: Prentice Hall. 2002.

RICCA, Domingos. Quem são as empresas familiares? São Paulo, 2005. Disponível em: <http://www. acionista.com.br/mercado/artigos_mercado/020310_domingos_ricca.htm >. Acesso em: 24 mar. 2010.

RONDEAU, A. A gestão dos conflitos nas organizações. In J. F. Chanlat (Coord.). O indivíduo na organização: dimensões esquecidas (Vol. 3). São Paulo: Atlas. 1996

ROSSATO NETO, F. J. Do mito do fundador ao mito do Edipo: possíveis contribuições psicanalíticas. In: ENCONTRO NACIONAL DE PROGRAMAS DE PÓS-GADRUAÇÃO EM ADMINISTRAÇÃO, 32., 2008. Rio de Janeiro, RJ. Anais... Rio de Janeiro, 2008.

SARDEMBERG, D. P. Conflito de Agência às Avessas: Rompendo com o Altruísmo Familiar. In: EnANPAD - Encontro da ANPAD, 33, 2009, São Paulo. Anais... São Paulo, 2009.

SCHEFFER, A. B. Fatores dificultadores e facilitadores do processo de sucessão familiar. Revista de Administração Contemporânea, v. 30, n. 3, jul/set de 1995, p. 80-90.

SOUSA, A. L. G.; AMARAL, G. H. O. A Organização do Pão: Um Estudo dos Controles em uma Empresa Familiar. In: Encontro de Estudos Organizacionais da ANPAD, 5. 2008. Belo Horizonte, MG. 18 a 20 de junho de 2008

TILLMANN, C.; GRZYBOVSKI, D. Sucessão de Dirigentes na Empresa Familiar: estratégias observadas na família empresária. Organizações \& Sociedade, v.12, n.32, p.45- 61, 2005.

TONDO, C.; PEREIRA, D. F. Planejamento de carreira para membros de famílias empresárias. In: TONDO, Cláudia. (org.). Desenvolvendo a empresa familiar e a família empresária. Porto Alegre: Sulina, 2008. p. 161-174. 2008

TUCKER, J. Change in Family Business. Family in Business, n. 25, Mar.-Apr., 2006.

VIDIGAL, Antônio Carlos. Viva a Empresa Familiar! Rio de Janeiro: Rocco, 1996.

VIEIRA, M. M. F. Por uma boa pesquisa (qualitativa) em administração. In: VIEIRA, M. M. F.; ZOUAIN, D. M. Pesquisa qualitativa em administração. Rio de Janeiro: editora FGV, 2004. p.13-28.

YIN, R. K. Estudo de caso: planejamento e método. 2. ed. Porto Alegre: Bookman, 2001. 